\title{
Multifocal neuropathy associated with West Nile virus infection
}

Figure Coronal short tau inversion recovery MRI demonstrating thickening and T2 signal prolongation in the
right (symptomatic) brachial plexus (broad arrow)

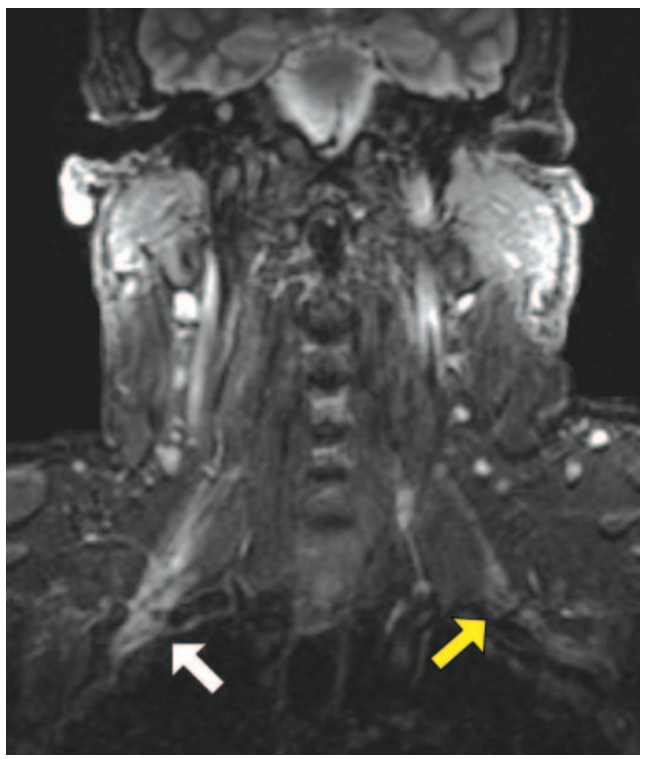

The contralateral (asymptomatic) brachial plexus (narrow yellow arrow) appears normal.

A 51-year-old man developed severe, subacute onset right facial weakness and flaccid, hyporeflexic right upper limb weakness several days following West Nile virus infection. Electrophysiologic and radiographic studies confirmed severe but incomplete right facial and brachial plexus neuropathies (figure). There were no clinical or laboratory findings to suggest encephalitis or myelitis. For additional details regarding his diagnosis, see appendix e-1 on the Neurology ${ }^{\circledR}$ Web site at www.neurology.org.

Since its arrival in North America, West Nile virus infection has been associated with a number of neuromuscular manifestations, ${ }^{1}$ such as a poliomyelitis-like motor neuronopathy, Guillain-Barré syndrome, isolated brachial plexus neuropathy, and now multifocal neuropathy. MRI continues to emerge as a useful tool in the evaluation of neuromuscular disorders. ${ }^{2}$

\section{Nathan Sumner, MD, and Lyell Jones, MD, Lackland AFB, TX}

Supplemental data at www.neurology.org
Disclosure: Dr. Jones has received federal grant support. Dr. Sumner has nothing to disclose.

Address correspondence and reprint requests to Dr. Nathan S. Sumner, Wilford Hall Medical Center, Department of Neurology, 2200 Bergquist Dr. Ste 1, Lackland AFB, TX 78236; Nathan.Sumner@lackland.af.mil

1. Jeha LE, Sila CA, Lederman RJ, Prayson RA, Isada CM, Gordon SM. West Nile virus infection: a new acute paralytic illness. Neurology 2003;61:55-59.

2. Zhou L, Yousem DM, Chaudhry V. Role of magnetic resonance neurography in brachial plexus lesions. Muscle Nerve 2004;30:305-309. 


\title{
Neurology
}

\author{
Multifocal neuropathy associated with West Nile virus infection \\ Nathan Sumner and Lyell Jones \\ Neurology 2008;71;1123 \\ DOI 10.1212/01.wnl.0000326964.26673.8e
}

This information is current as of September 29, 2008

\author{
Updated Information \& \\ Services \\ Supplementary Material \\ References \\ Permissions \& Licensing \\ Reprints
}

including high resolution figures, can be found at: http://n.neurology.org/content/71/14/1123.full

Supplementary material can be found at: http://n.neurology.org/content/suppl/2008/09/26/71.14.1123.DC1

This article cites 2 articles, 1 of which you can access for free at: http://n.neurology.org/content/71/14/1123.full\#ref-list-1

Information about reproducing this article in parts (figures,tables) or in its entirety can be found online at:

http://www.neurology.org/about/about_the_journal\#permissions

Information about ordering reprints can be found online:

http://n.neurology.org/subscribers/advertise

Neurology ${ }^{\circledR}$ is the official journal of the American Academy of Neurology. Published continuously since 1951, it is now a weekly with 48 issues per year. Copyright . All rights reserved. Print ISSN: 0028-3878. Online ISSN: 1526-632X.

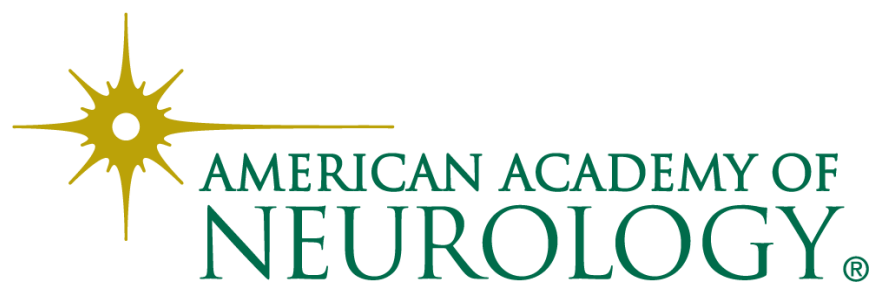

